\title{
Sistem Pendukung Keputusan Penerima Program Subsidi RASTRA Dengan Metode Simple Additive Weighting (SAW)
}

\author{
Dindo Sarwono \\ Universitas Muhammadiyah Surakarta \\ Surakarta, Indonesia \\ Sarwonodindo014@gmail.com
}

\begin{abstract}
Abstraksi - Program subsidi Rastra (Beras Rakyat Sejahtera) merupakan program dari presiden untuk upaya peningkatan pendapatan para petani, ketahanan pangan, pengebangan ekonomi pedesaan dan stabilitas ekonomi nasional. Dan bertujuan untuk membatu masyarakat berpenghasilan rendah. Dalam pendistribusian Program Subsidi Rastra di Kelurahan Blumbang masih terjadi permasalahan akibatnya program tersebut tidak tepat sasaran, untuk mengatasi masalah tersebut maka diperlukan sebuah aplikasi komputer yang dapat membantu mengambil sebuah keputusan yang tepat. Subjek dalam penelitian ini adalah aplikasi Sistem Pendukung Keputusan Penerima Program Subsidi Rastra dengan Metode Simple Additive Weighting (SAW). Metode SAW dikenal dengan istilah metode penjumlahan berbobot, dengan konsep mencari penjumlahan terbobot dari rating kinerja pada setiap alternatif. Hasil penelitian bahwa aplikasi Sistem Pendukung Keputusan Penerima Program Subsidi Rastra dapat membantu mengambil keputusan yang tepat dalam pendistribusian program Subsidi Rastra, sehingga program tersebut dapat terditribusi dengan tepat sasaran dan tidak ada kecurangan.
\end{abstract}

Katakunci - Beras Rakyat Sejahtera; Sistem Pendukung Keputusan; Simple Additive Weighting

\section{PENDAhuluan}

Program Subsidi Rastra (Beras Rakyat Sejahtera) adalah bagian dari Sistem Ketahana Pangan Nasional, program ini diadakan untuk mencapai kemandirian dan kedaulatan pangan. Karena pangan merupakan komoditas strategis yang dilindungi oleh Undang-Undang Dasar Negara Republik Indonesia Tahun 1945. Program Rastra (Beras Rakyat Sejahtera) merupakan program dari Presiden tentang kebijakan perberasan nasional. Presiden memberi arahan kepada Mentri dan Kepala Lembaga non Kementrian, Gubernur, dan Bupati/Walikota di Indonesia untuk upaya peningkatan pedapatan para petani, Ketahanan pangan, pengembangan ekonomi pedesaan dan stabilitas ekonomi nasional. Perum BULOG secara khusus diperintahkan untuk menyediakan dan menyalurkan beras bersubsidi bagi masyarakat berpenghasilan rendah, dan penyediaan beras mengutamakan pengadaan beras/gabah dari para petani di Indonesia [5]

Beras merupakan makanan pokok sebagaian besar penduduk indonesia. Dengan demikian, beras menjadi komoditas yang sangat penting bagi warga masyarakat yang berpenghasilan rendah yang bertujuan untuk mengurangi beban pengeluaran para Keluarga Sasaran Penerima Manfaat (KPM) dalam memenuhi kebutuhan pangan pokok sebagai salah satu hak dasarnya [5].

Di Kelurahan Blumbang, Kecamatan Tawangmangu merupakan tempat pendistribusian Program Subsidi Rastra (Beras Rakyat Sejahtera) untuk keluarga miskin, Program tersebut mencakup kriteria seperti berikut: penghasilan perbulan, pekerjaan, jumlah tanggungan keluarga, kondisi rumah, kendaraan yang dimiliki, dan jumlah tagihan listrik perbulan, cakupan tersebut digunakan untuk menetukan bobot dari setiap kriteria dalam penerimaan subsidi Rastra. Dalam menetukan penerima program subsidi Rastra masih menggunakan penilaian secara subjektif. Penilaian calon penerima program tersebut masih menggunakan cara manual dan belum adanya komputerisasi dalam menentukan penerima Program Subsidi Rastra. Pertama kali pengumpulan data terlebih dahulu menurut KK miskin oleh RT setempat, kemudian dihitung secara manual dengan kategori kemiskinan yang terjadi pada keluarga tersebut. Dengan demikian dalam pendistribusian Program Subsidi Rastra yang ditujukan kepada warga masyarakat yang berpenghasilan rendah atau miskin yang tidak tepat sasaran. Sehingga diperlukan sebuah Sistem Pendukung Keputusan yang dapat mengatasi masalah tersebut, dan sistem ini berguna untuk memudahkan pengambilan keputusan yang terkait dengan masalah calon penerima Program Rastra untuk warga masyarakat berpenghasilan rendah, sehingga akan didapatkan keluarga yang paling layak diberi Rastra.

Sistem Pendukung Keputusan (SPK) merupakan bagian dari sistem informasi berbasis komputer yang menyediakan 
informasi, pemodelan, dan pemanipulasian data. Sistem itu dapat digunakan untuk mempermudah pengambilan keputusan dalam situasi yang semi terstruktur dan tidak terstruktur, dimana tak seorang pun mengerti secara pasti bagaimana keputusan seharusnya harus dibuat [3]. Sistem pendukung keputusan biasanya dibangun untuk mendukung solusi untuk suatu masalah atau untuk mengevakuasi suatu peluang [9]. Sistem pendukung keputusan adalah bagian integral dari keseluruhan sistem organisasi secara keseluruhan. Sistem organisasi mencakup sistem fisik, sistem keputusan, dan sistem informasi [6].

Sistem Pendukung Keputusan memiliki beberapa metode, salah satunya adalah Metode simple addtitive weighting ( SAW), metode SAW merupakan salah satu metode untuk memecahkan masalah pengambilan keputusan multi atribut [7]. Metode SAW yang sering dikenal dengan metode penjumlahan berbobot, konsep dasar metode SAW adalah mencari penjumlahan terbobot dari rating kinerja pada setiap alternatif, metode SAW juga memiliki kelebihan seperti, metode SAW lebih mudah di pahami, metode SAW dapat melakukan penilaian secara lebih tepat, sesuai dengan kriteria dan bobot yang sudat ditentukan. Metode SAW juga dapat memilih secara tepat alternatif terbaik dari sejumlah alternatif yang ada. Metode SAW juga memiliki kekurangan seperti, data yang akan dimasukkan harus tepat dan benar, agar tidak terjadi kesalahan saat perangkingan. Keakuratan data masih sedikit kurang karena kriteria yang telah ditetapkan harus dinamis dan memiliki cakupan yang luas [4].

\section{METODE}

\section{A. Teknik Pengumpulan Data}

Membuat dan merancang Sistem Pendukung Keputusan penerima Rastra, dibutuhkan data-data dan informasi sebagai bahan untuk kebenaran materi uraian dan pembahasan. Sebelum membuat dan merancang Sistem Pendukung Keputusan tersebut perlu pemgambilan data awal. Penulis melakukan pengumpulan data awal menggunakan metode Interview / wawancara, wawancara yang dilakukan terkait dengan kriteria - kriteria yang mencakup para penerima Rastra. Di Kelurahan Blumbang saya beremu langsung dengan Bapak Santoso S.sos selaku Lurah di Desa Blumbang. Berdasarkan hasil wawancara tersebut didapatkan data, yang akan di olah kemudian akan didapatkan siapa yang berhak menerima program Subsidi Rastra menggunakan metode SAW.

\section{B. Analisi Kebutuhan}

Untuk mendapatkan teknologi yang tepat guna, Penelitian bersubyek "Sistem Pendukung Keputusan Penerima Program Subsidi Rastra menggunakan metode SAW". Peralatan yang di gunakan berupa Hardware dan Softwaresebagai berikut:

1 Hardware
a) Prosesor Intel Core I3 3217U
b) Harddisk $500 \mathrm{~GB}$
c) RAM \$GB DDR3 Memory

\section{Software}
a) Microsoft Visual Studio 2017
b) Microsoft office Access 2012 sebagai Database

\section{Simple Additive Weighting}

Metode Simple Additive Weighting (SAW) kerap disebut dengan metode penjumlahan berbobot. Rancangan alur metode $S A W$ adalah memecahkan penjumlahan berbobot dari rating kinerja pada setiap alternatif pada semua atribut. Metode SAW memerlukan proses normalisasi matriks keputusan (X) kesuatu skala yang dapat diperbandingkan dengan semua alternatif yang ada [8]

Metode SAW memerlukan mekanisme normalisasi matriks keputusan (X) untuk skala yang dapat dibandingkan dengan semua alternatif. Metode ini mempunyai rumus seperti persamaan (1) dan (2).

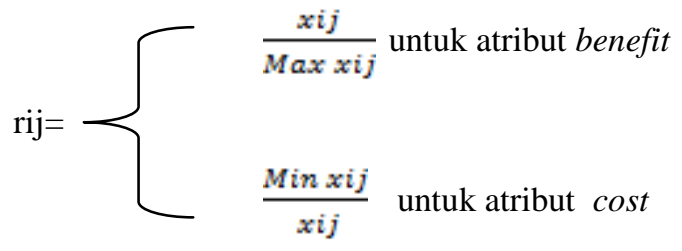

Dimana :

rij $=$ Nilai rating kinerja

Xij = Nilai kinerja dari setiap rating

Max $x i j=$ Nilai terbesar dari setiap kriteria

Min $x i j j=$ Nilai terkecil dari tiap kriteria

$V i=\sum_{j=l}^{n} W j R i j$

Dimana :

$\mathrm{Vi}=$ Nilai akhir dari alternatif

wj = Bobot yang telah di tentukan

rij = Normalisai matriks 
Nilai Vi - yang lebih besar mengidentikasikan bahwa alternatif Ai lebih terpilih.

Pada persamaan (1) diperoleh dua atribut yaitu berupa cost dan benefit. Jika cost nilai yang terkecil yang dipakai sementara untuk benefit, nilai yang terbesar yang dipakai. Untuk melakukan penghitungan yang berupa penerapan guna mencapai alternatif yang memiliki nilai tertinggi. Pada metode ini, perlu ditentukan atribut benefit atau cost dari kriteria yang dibuat dan memilih bobot setiap kriteria. Hal ini digunakan untuk memilih pengunaan persamaan dan nilai bobot dari setiap kriteria untuk proses seleksi. Kriteria dan bobot disajikan pada tabel 1 dan 2 .

TABEL I. Tegangan Dan Arus Keluaran PiezoeleKtrik RANGKAIAN PARALEL DAN SER

\begin{tabular}{|c|l|c|}
\hline Kriteria & Variable & Bobot \\
\hline Penghasilan perbulan & $\mathrm{C} 1$ & 6 \\
\hline Pekerjaan & $\mathrm{C} 2$ & 5 \\
\hline $\begin{array}{c}\text { Jumlah Tanggungan } \\
\text { Keluarga }\end{array}$ & $\mathrm{C} 3$ & 4 \\
\hline $\begin{array}{c}\text { Kondisi Rumah } \\
\text { Kendaraan yang } \\
\text { Dimiliki }\end{array}$ & $\mathrm{C} 4$ & 3 \\
\hline $\begin{array}{c}\text { Tagihan Listrik } \\
\text { per Bulan }\end{array}$ & $\mathrm{C} 5$ & 2 \\
\hline
\end{tabular}

TABEL II. TABEL BOBOT KRITERIA

\begin{tabular}{|c|c|c|}
\hline Kriteria & Nilai & Bobot \\
\hline Penghasilan per Bulan & $<500.000$ & 5 \\
\hline & $500.000-$ & 4 \\
& 1.000 .000 & \\
\hline & $1.100 .000-$ & 3 \\
& 2.000 .000 & \\
\hline & $2.100 .000-$ & 2 \\
& 3.000 .000 & \\
\hline
\end{tabular}

\begin{tabular}{|c|c|c|}
\hline Kriteria & Nilai & Bobot \\
\hline & $>3.000 .000-$ & 1 \\
\hline \multirow[t]{5}{*}{ Pekerjaan } & Buruh & 5 \\
\hline & Petani & 4 \\
\hline & Pedagang & 3 \\
\hline & PNS & 2 \\
\hline & Pengusaha & 1 \\
\hline \multirow[t]{5}{*}{ Jumlah Tanggungan keluarga } & $>8$ orang & 5 \\
\hline & 6-7 orang & 4 \\
\hline & $5-6$ orang & 3 \\
\hline & 3-4 orang & 2 \\
\hline & 1-2 orang & 1 \\
\hline \multirow[t]{5}{*}{$\begin{array}{c}\text { Kondisi Rumah dinding dan } \\
\text { lantai }\end{array}$} & Papan \& Tanah & 5 \\
\hline & Papan \& Plester & 4 \\
\hline & $\begin{array}{l}\text { Tembok \& } \\
\text { Tanah }\end{array}$ & 3 \\
\hline & $\begin{array}{c}\text { Tembok \& } \\
\text { Plester }\end{array}$ & 2 \\
\hline & $\begin{array}{c}\text { Tembok \& } \\
\text { Kramik }\end{array}$ & 1 \\
\hline \multirow[t]{4}{*}{ Kendaraan yang dimiliki } & Tidak Punya & 4 \\
\hline & Sepeda & 3 \\
\hline & Sepeda motor & 2 \\
\hline & Mobil & 1 \\
\hline \multirow[t]{5}{*}{ Tagihan Listrik per Bulan } & $<$ RP. 20.000 & 5 \\
\hline & $\begin{array}{l}\text { RP. } 20.000- \\
\text { Rp. } 40.000\end{array}$ & 4 \\
\hline & $\begin{array}{l}\text { RP. } 40.000- \\
\text { Rp. } 60.000\end{array}$ & 3 \\
\hline & $\begin{array}{l}\text { RP. } 60.000- \\
\text { Rp. } 80.000\end{array}$ & 2 \\
\hline & > RP. 80.000 & 1 \\
\hline
\end{tabular}




\section{Tahap pengembangan}

Algoritma simple addtitive weighting ( SAW) yang digunakan dalam penelitian ini mengikuti alur / flowchart seperti yang ditampilkan pada Gambar 1 .

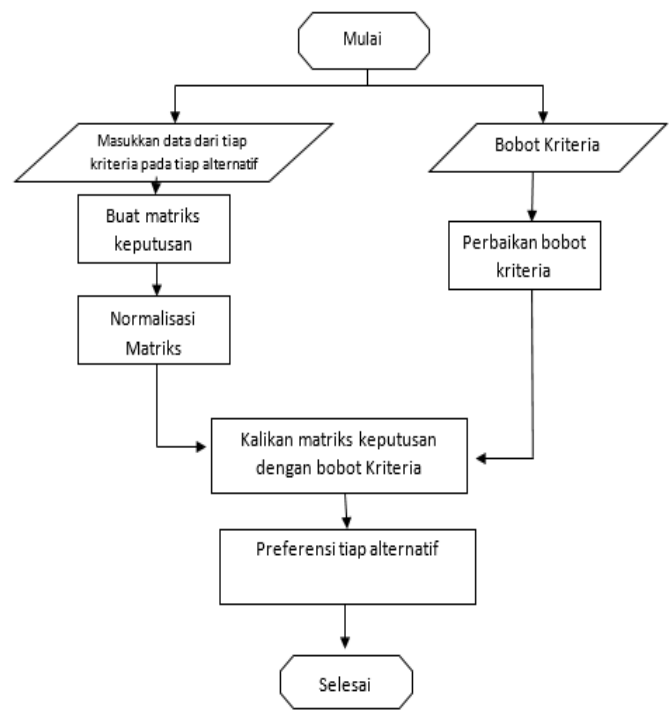

Gambar 1. Flow Chart Algoritma Metode SAW

Tahap - tahap yang ada dalam algoritma adalah sebagai berikut.

\section{Proses Memilih Bobot Kriteria.}

Pada proses ini digunakan untuk memilih kriteria dan bobot yang akan dikalikan tiap kriteria pada alternatif yang ada.

2 Proses Pembaharuan / memperbaiki bobot.

Pada proses ini digunakan untuk menupdate/ memperbaharui nilai yang telah dibuat.

3 Proses Memasukkan data.

Pada proses ini digunakan untuk menmasukkan data tiap peserta penerima program rastra yang telah ada.

4 Proses Membuat matriks.

Dimana pada proses ini data yang dimasukkan dalam kolom kriteria dibuat matriks keputusan pada setiap alternatif

5 Proses Normalisasi matriks.

Tahapan ini melakukan normalisasi dari setiap matriks keputusan tiap alternatif yang ada.

6 Proses Perkalian matriks normalisasi dengan bobot kriteria.

Tahapan ini perkalian antara hasil dari normalisasi matriks dengan bobot kriteria

7 Proses preferensi tiap alternatif.

Proses ini berupa nilai dari perkalian antara hasil dan normalisasi matriks dengan bobot kriteria, dimana tiap alternatif akan memiliki nilai masing-masing yang berupa nilai keputusan.

\section{HASIL DAN PEMBAHASAN}

\section{A. Hasil perhitungan Manual dengan metode SAW}

Contoh hasil dari lima input data calon penerima tdisajikan pada Tabel 3. Selanjutnya normalisasi dilakukan sesuai dengan atribut dan kriteria yang telah tentukan, hasil normalisasi disajikan pada Tabel 4 .

TABEL 3. CONTOH DATA CALON PENERIMA

\begin{tabular}{|c|c|c|c|c|c|c|}
\hline Nama & C1 & $\mathrm{C} 2$ & C3 & $\mathrm{C} 4$ & C5 & $\mathrm{C} 6$ \\
\hline Atmo & 900000 & Burah & 2 & $\begin{array}{l}\text { Tembolk \& } \\
\text { Plester }\end{array}$ & $\begin{array}{l}\text { Sepeda } \\
\text { motor }\end{array}$ & $\begin{array}{c}\text { RP. } 20.000 \\
\text { - } R_{p} \\
40.000\end{array}$ \\
\hline Gixante & 1000000 & Petani & 3 & $\begin{array}{c}\text { Tembok \& } \\
\text { kramiks }\end{array}$ & $\begin{array}{l}\text { Sepeda } \\
\text { motor }\end{array}$ & $\begin{array}{c}\text { RP. } 20.000 \\
\text { - } R_{R} \\
40.000\end{array}$ \\
\hline Give. & 500000 & Buruh & 3 & $\begin{array}{l}\text { Tembok \& } \\
\text { Plester }\end{array}$ & $\begin{array}{l}\text { Tidak } \\
\text { punya }\end{array}$ & $\begin{array}{c}\text { RP. } 20.000 \\
\text { - Rp } \\
40.000\end{array}$ \\
\hline Jumadi & 1200000 & Petani & 2 & $\begin{array}{l}\text { Tembok \& } \\
\text { Plester }\end{array}$ & $\begin{array}{l}\text { Sepeda } \\
\text { motor }\end{array}$ & $\begin{array}{c}\text { RP. } 60.000 \\
-R p \\
80.000\end{array}$ \\
\hline Widodo & 2000000 & Pas & 3 & $\begin{array}{l}\text { Tembols \& } \\
\text { kramiks }\end{array}$ & Mobil & $\begin{array}{c}\text { RP. } 60.000 \\
\text { - } R_{p} \\
80.000\end{array}$ \\
\hline
\end{tabular}

TABEL 4. RATING KECOCOKAN

\begin{tabular}{|c|c|c|c|c|c|c|}
\hline Nama & C1 & C2 & C3 & C4 & C5 & C6 \\
\hline A1 & 4 & 5 & 3 & 2 & 3 & 1 \\
\hline A2 & 4 & 4 & 3 & 1 & 3 & 2 \\
\hline A3 & 5 & 5 & 5 & 2 & 3 & 2 \\
\hline A4 & 3 & 4 & 3 & 2 & 1 & 1 \\
\hline A5 & 3 & 2 & 2 & 1 & 1 & 2 \\
\hline
\end{tabular}

\section{Pembuatan Matriks keputusan}

Pengambilan keputusan memberi bobot, berdasarkan tingkat kepentingan masing-masing kriteria yang dibuat dari tabel kriteria sebagai berikut :

Vaktor Bobot : $\mathrm{W}=\{6,5,4,3,2,1\}$

Membuat matriks keputusan $\mathrm{x}$, dibuat dari tabel rating kecocokan sebagai berikut : 


$$
X=\left\{\begin{array}{llllll}
4 & 5 & 3 & 2 & 3 & 1 \\
4 & 4 & 3 & 1 & 3 & 2 \\
5 & 5 & 5 & 2 & 3 & 2 \\
3 & 4 & 3 & 2 & 1 & 1 \\
3 & 2 & 2 & 1 & 1 & 2
\end{array}\right\}
$$

Selanjutnya, normalisasi matriks x berdasarkan matriks diatas sebagai berikut:

$$
\begin{aligned}
& \mathrm{A} 1=\mathrm{R} 11=\frac{4}{\max [4,4,5,3,3]}=\frac{4}{5}=0.8 \\
& \mathrm{R} 12=\frac{5}{\max \{5,4,5,4,2\}}=\frac{5}{5}=1 \\
& \mathrm{R} 13=\frac{3}{\max \{3,3,5,3,2\}}=\frac{3}{2}=0.6 \\
& \mathrm{R} 14=\frac{2}{\max \{2,1,2,2,1\}}=\frac{2}{2}=1 \\
& \mathrm{R} 15=\frac{3}{\max \{3,3,3,1,1\}}=\frac{3}{3}=1 \\
& \mathrm{R} 16=\frac{1}{\max \{1,2,2,1,2\}}=\frac{1}{2}=0.5 \\
& \mathrm{~A} 2=\mathrm{R} 21=\frac{4}{\max [4,4,5,3,3]}=\frac{4}{5}=0.8 \\
& \mathrm{R} 22=\frac{4}{\max \{5,4,5,4,2\}}=\frac{4}{5}=0.8 \\
& \mathrm{R} 23=\frac{3}{\max \left\{33_{z}, 5,3,2\right\}}=\frac{3}{5}=0.6 \\
& \mathrm{R} 24=\frac{1}{\max \{2,1,2,2,1\}}=\frac{1}{2}=0.5 \\
& \mathrm{R} 25=\frac{3}{\max \{3,3,3,1,1\}}=\frac{3}{3}=1 \\
& \mathrm{R} 26=\frac{2}{\max \{1,2,2,1,2\}}=\frac{2}{2}=1 \\
& \mathrm{~A} 3=\mathrm{R} 31=\frac{5}{\max \{4,4,5,3,3\}}=\frac{5}{5}=1 \\
& \mathrm{R} 32=\frac{5}{\max \{5,4,5,4,2\}}=\frac{5}{5}=1 \\
& \mathrm{R} 33=\frac{5}{\max \{3,3,5,3,2\}}=\frac{5}{5}=1 \\
& \mathrm{R} 34=\frac{2}{\max \{2,1,2,2,1\}}=\frac{2}{2}=1 \\
& \mathrm{R} 35=\frac{3}{\max \{3,3,3,1,1\}}=\frac{3}{3}=1 \\
& \mathrm{R} 36=\frac{2}{\max \{1,2,2,1,2\}}=\frac{2}{2}=1 \\
& \mathrm{~A} 4=\mathrm{R} 41=\frac{3}{\max \{4,4,5,3,3]}=\frac{3}{5}=0.6 \\
& \mathrm{R} 42=\frac{4}{\max \{5,4,5,4,2\}}=\frac{4}{5}=0.8 \\
& \mathrm{R} 43=\frac{3}{\max \left\{33_{n}, 5,3,2\right\}}=\frac{3}{5}=0.6 \\
& \mathrm{R} 44=\frac{2}{\max \{2,1,2,2,1\}}=\frac{2}{2}=1 \\
& \mathrm{R} 45=\frac{1}{\max \{3,3,3,1,1\}}=\frac{1}{3}=0.3
\end{aligned}
$$

$$
\begin{aligned}
& \mathrm{R} 46=\frac{1}{\max \{1,2,2,1,2\}}=\frac{1}{2}=0.5 \\
& \mathrm{~A} 5=\mathrm{R} 51=\frac{3}{\max \{4,4,5,3,3]}=\frac{3}{5}=0.6 \\
& \mathrm{R} 52=\frac{2}{\max \{5,4,5,4,2\}}=\frac{2}{5}=0.4 \\
& \mathrm{R} 53=\frac{2}{\max \left\{3 z_{n}, 5,3,2\right\}}=\frac{2}{5}=0.4 \\
& \mathrm{R} 54=\frac{1}{\max \{2,1,2,2,1\}}=\frac{1}{2}=0.5 \\
& \mathrm{R} 55=\frac{1}{\max \{3,3,3,1,1\}}=\frac{1}{3}=0.3 \\
& \mathrm{R} 56=\frac{2}{\max \{1,2,2,1,2\}}=\frac{2}{2}=1
\end{aligned}
$$

Sehingga diperoleh matriks ternormalisasi r sebagai berikut :

$$
\mathrm{R}=\left\{\begin{array}{llllcc}
0.8 & 1 & 0.6 & 1 & 1 & 0.5 \\
0.8 & 0.8 & 0.6 & 0.5 & 1 & 1 \\
1 & 1 & 1 & 1 & 1 & 1 \\
0.6 & 0.8 & 0.6 & 1 & 0.3 & 0.5 \\
0.6 & 0.4 & 0.4 & 0.5 & 0.3 & 1
\end{array}\right\}
$$

Proses perangkingan diperoleh sebagai berikut :

$\mathrm{W} * \mathrm{R}$ :

$$
\begin{aligned}
& \text { V1 }=(6)(0.8)+(5)(1)+(4)(0.6)+(3)(1)+(2)(1)+(1)(0.5) \\
& =17.7 \\
& \text { V2=(6)(0.8)+(5)(0.8)+(4)(0.6)+(3)(0.5)+(2)(1)+(1)(1) } \\
& =15.7 \\
& \text { V3=(6)(1)+(5)(1)+(4)(1)+(3)(1)+(2)(1)+(1)(1) } \\
& =21 \\
& \text { V4=(6)(0.6)+(5)(0.8)+(4)(0.6)+(3)(1)+(2)(0.3)+(1)(0.5) } \\
& =14.1667 \\
& \text { V5=(6) }(0.6)+(5)(0.4)+(4)(0.4)+(3)(0.5)+(2)(0.3)+(1)(1) \\
& =10.3667
\end{aligned}
$$

\section{Hasil Penghitungan manual dengan metode $S A W$}

Berikut hasil penghitungan manual menggunakan metode SAW, hasil penilaian disajikan pada Tabel 5 .

TABEL 5. HASIL PENILAIAN

\begin{tabular}{|c|l|l|}
\hline No. & \multicolumn{1}{|c|}{ Nama } & \multicolumn{1}{|c|}{ Hasil } \\
\hline 1. & Giyo & 21 \\
\hline 2. & Atmo & 17.7 \\
\hline 3. & Giyanto & 15.7 \\
\hline 4. & Jumadi & 14.1667 \\
\hline 5. & Widodo & 10.3667 \\
\hline
\end{tabular}

Pengurutan hasi dari nilai terbesar ke terkecil disajikan pada tabel 6 , dan nilai terbesar adalah alternatif yang terpilih 
sebagai alternatif terbaik. Dengan kata lain, warga yang pertama yang berhak mendapatkan bantuan beras.

TABel 6. PENGURUtAN Hasi DARI NILAI TERBESAR KE TERKECIL

\begin{tabular}{|c|l|l|}
\hline No. & \multicolumn{1}{|c|}{ Nama } & \multicolumn{1}{|c|}{ Hasil } \\
\hline 1. & Giyo & 17,7 \\
\hline 2. & Atmo & 15,7 \\
\hline 3. & Giyanto & 21 \\
\hline 4. & Jumadi & 14.1667 \\
\hline 5. & Widodo & 10.1667 \\
\hline
\end{tabular}

\section{Hasil aplikasi Sistem Pendukung Keputusan Penerima} Program Subsidi Rastra dengan metode Simple Additive Weighting (saw).

Berikut Hasil aplikasi Sistem Pendukung Keputusan Penerima Program Subsidi Rastra dengan metode Simple Additive Weighting (saw).

Menu utama pada aplikasi ini merupakan tampilan awal dari beberapa menu yang ada didalam aplikasi ini, diantaranya adalah menu master, perhitungan, peringkat dan window. Gambar 2 menunjukkan tampilan menu utama.

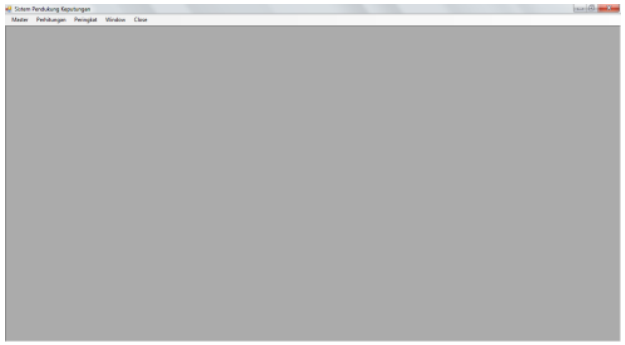

Gambar 2. Menu Utama

Menu dala calon penerima berfungsi untuk menginputkan data dari calon penerima yang akan diseleksi, menu ini digunakan utuk menyipan, mengedit, menghapus data calon penerima. Menu ini berisi NIK, Nama, Alamat, No Telepon, dan Kriteri calon penerima. Gambar 3 menunjukkan tampilan menu data calon penerima.

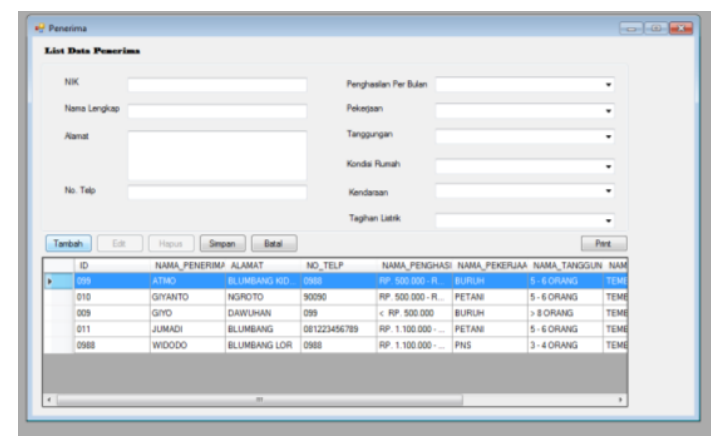

Gambar 3. Menu Data Calon Penerima
Menu penghitungan digunakan untuk proses penghitungan dengan menggunakan metode $S A W$ dan terdapat dua tabel yaitu tabel kriteria dan tabel normalisasi. Tabel kriteria terdiri dari beberapa nilai dari sebuah kriteria dan tabel normalisasi terdiri dari nilai hasil analisa dengan menggunakan metode SAW. Gambar 4 menujukkan menu penghitungan.

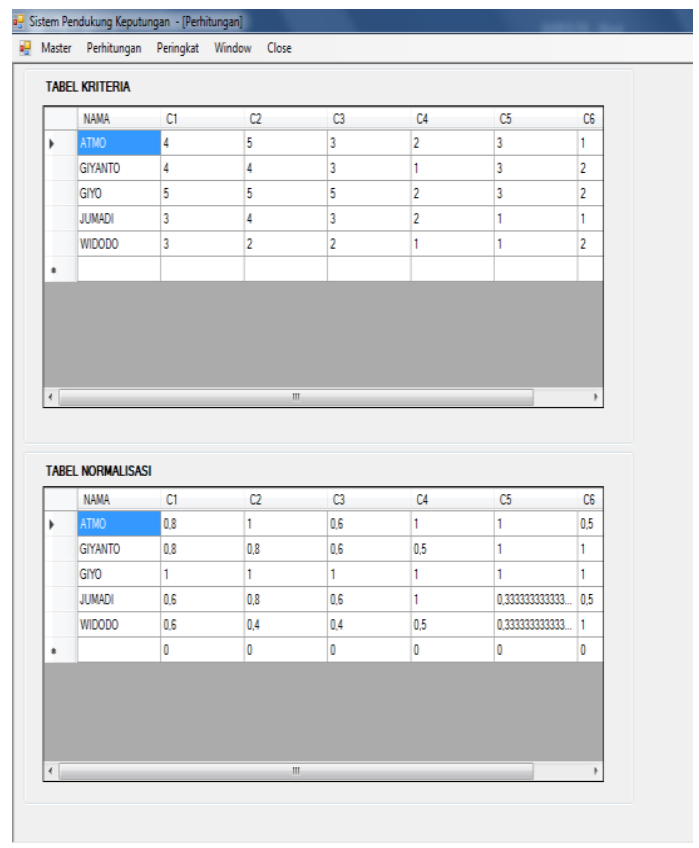

Gambar 4. Menu Penghitungan

Menu peringkat digunakan untuk menampilkan hasil dari penghitungan dengan metode $S A W$. Menu ini terdapat jumlah nilai dari setiap calon penerima, dari nilai terbesar ke nilai terkecil. Gambar 5 menujukkan menu Peringkat.

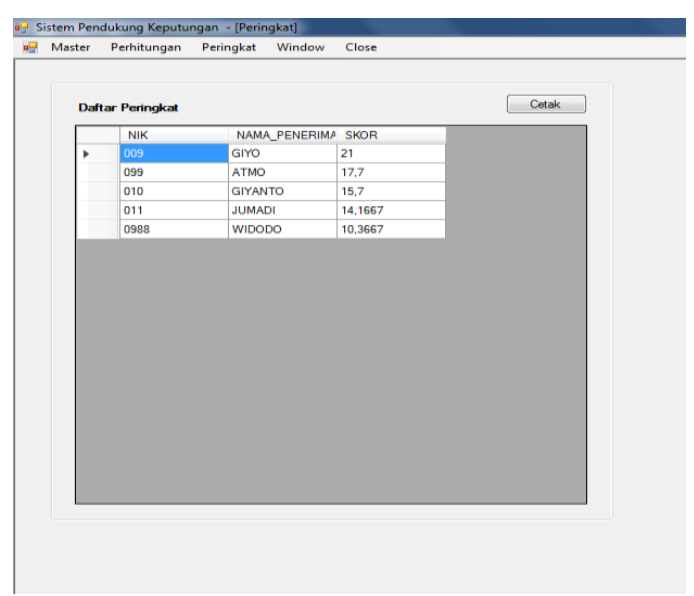

Gambar 5. Menu Peringkat 


\section{KESIMPULAN}

Dengan adanya sistem pendukung keputusan penerima program subsidi rastra dapat membatu proses pendistribusian beras bersubsidi bagi masyarakat berpenghasilan rendah di Kelurahan Blumbang, sesuai kriteria yang telah ditentukan sebelumnya, sehingga meminimalisir kecurangan dan proses penyaluran beras bersubsidi tepat sasaran. Dalam penelitian ini Peggunaan metode SAW mampu memilih secara tepat alternatif terbaik dari sejumlah alternatif yang ada sesuai dengan kriteria yang telah ditentukan sehingga metode SAW yang diterapkan pada sistem berhasil diimplementasikan, dan dapat memberi keputusan siapa saja yang berhak dan tidak berhak menerima beras rakyak sejahtera tersebut.

\section{DAFTAR PUSTAKA}

[1] R. T. Pahlevy, "Rencana Bangun Sistem Pendukung Keputusan Menentukan penerima Beasiswa dengan Menggunakan metode Simpele Additive Weighting (SAW)," Skripsi Program Studi Tehnik Informatika, 2010.

[2] A. S. Rini, "Sistem Pendukung Keputusan Seleksi Penerimaan Beras Untuk Keluarga Miskin Dengan Metode Simple Additive Weighting," Jurnal Sarjana Teknik Informatiks, 2014.
[3] Kusrini, Konsep dan Aplikasi Sistem Pendukung Keputusan, Yogyakarta : Andi, 2007.

[4] S. Kusumadewi, Fuzzy Multi-Attribute Desicion Making (Fuzzy FAMDM), Yogyakarta: Graha Ilmu, 2006.

[5] T. K. R. Pusat, Pedoman Umum Subsidi Rastra, Jakarta: Sekretaris Kementerian Koordinator Bidang Pembangunan Manusia Dan Kebudayaan Republik Indonesia, 2017.

[6] Risawandi dan R. R, "Study of the Simple Multi-Attribute Rating Technique For Decision Support," International Journal of Scientific Research in Science and Technology (IJSRST), vol. 2, no. 6, pp. 491-494, 2016.

[7] A. L dan R. A. C, "Simple Additive Weighting Methods of Multi criteria Decision Making and Applications: A Decade Review," International Journal of Information Processing and Management(IJIPM), vol. 5, no. 1, pp. 39-49, 2014.

[8] S. Eniyati, "Perancangan Sistem Pendukung Keputusan Pengambil Keputusan untuk Penerimaan Beasiswa dengan Metode SAW (Simple Additive weighting).," Jurnal Teknologi DINAMIK, vol. 16, no. 2, 2011.

[9] K. M, Simare-mare dan S. A. P. U. , "Decision Support System in Selecting The Appropriate Laptop Using Simple Additive Weighting," International Journal of Recent Trends in Engineering \& Research, vol. 2, no. 12, pp. 215-222, 2016. 